Article

\title{
Preparation of a p-n heterojunction 2D BiOI nanosheet/1DBiPO nanorod composite electrode for enhanced visible light photoelectrocatalysis
}

\author{
Sen Liu, Mengyu Zhao, Zetian He, Yi Zhong, Hao Ding, Daimei Chen * \\ Beijing Key Laboratory of Materials Utilization of Nonmetallic Minerals and Solid Wastes, National Laboratory of Mineral Materials, School of Materials \\ Science and Technology, China University of Geosciences, Beijing 100083, China
}

\section{A R T I C L E I N F O}

\section{Article history:}

Received 31 August 2018

Accepted 13 October 2018

Published 5 March 2019

\section{Keywords:}

Electrodeposition

Photoelectrocatalysis

$\mathrm{BiOI} / \mathrm{BiPO}_{4} / \mathrm{FTO}$

Tetracycline

\begin{abstract}
A B S T R A C T
In this study, a 2D BiOI nanosheet/1D $\mathrm{BiPO}_{4}$ nanorod/fluorine-doped tin oxide (FTO) composite electrode with a p-n heterojunction structure was prepared by a two-step electrodeposition method. Field-emission scanning electron microscopy, transmission electron microscopy, X-ray photoelectron spectroscopy, UV-visible diffuse reflectance spectroscopy, and electrochemical testing were used to characterize its composition, crystal morphology, and optical properties. The Bi$\mathrm{OI} / \mathrm{BiPO}_{4} / \mathrm{FTO}$ composite electrode has higher photoelectrocatalytic (PEC) activity for the degradation of tetracycline than pure $\mathrm{BiPO}_{4}$ and BiOI. The PEC activity of the composite was 1.98 times and 2.46 times higher than those of the $\mathrm{BiOI} / \mathrm{FTO}$ and $\mathrm{BiPO}_{4} / \mathrm{FTO}$ electrodes, respectively. The effects of the working voltage and BiOI deposition time on the degradation of tetracycline were investigated. The optimum BiOI deposition time was found to be $150 \mathrm{~s}$ and the optimum working voltage is $1.2 \mathrm{~V}$. Trapping experiments showed that hydroxyl radicals $(\bullet \mathrm{OH})$ and superoxide radicals $\left(\bullet \mathrm{O}_{2}^{-}\right)$are the major reactive species in the $\mathrm{PEC}$ degradation process. The $\mathrm{BiOI} / \mathrm{BiPO}_{4} / \mathrm{FTO}$ composite electrode has good stability, and the tetracycline removal efficiency remains substantially unchanged after four cycles in a static system. The reason for the PEC efficiency enhancement in the $\mathrm{BiOI} / \mathrm{BiPO}_{4} / \mathrm{FTO}$ composite electrode is the increased visible light absorption range and the p-n heterojunction structure, which promotes the separation and migration of the photogenerated electrons and holes.

(C) 2019, Dalian Institute of Chemical Physics, Chinese Academy of Sciences. Published by Elsevier B.V. All rights reserved.
\end{abstract}

\section{Introduction}

The pollution of water with toxic substances has drawn significant attention because of the risks to the environment and public health. Many traditional methods of water treatment, such as adsorption [1], biological oxidation [2], flocculation-precipitation [3], electrochemical catalytic oxidation, and photocatalysis [4-7], have been investigated for the removal of organic compounds from wastewater. Among them, photoca- talysis is regarded as a promising and "green" sewage treatment technology because of its strong oxidation ability, low cost, and environmental friendliness [8-10]. However, photocatalyst technology is far from practical application because of the high recombination efficiency of the electron-hole pairs and low quantum efficiency $[11,12]$. In addition, the separation and recovery of the photocatalyst powder from treated water is challenging, which limits the efficiency and stability of the catalyst [13-15]. Compared with separate photocatalysis and

\footnotetext{
* Corresponding author. Tel: +86-15801558907; E-mail: chendaimei@cugb.edu.cn

This work was partly supported by the National Natural Science Foundations of China (21577132) and the Fundamental Research Funds for the Central Universities (2652017377, 2652017378).

DOI: 10.1016/S1872-2067(18)63186-9 | http://www.sciencedirect.com/science/journal/18722067 | Chin. J. Catal., Vol. 40, No. 3, March 2019
} 
electrooxidation processes, the combination of semiconductor photocatalysis and electrochemical oxidation (photoelectrocatalysis, PEC) for the degradation of organic contaminants in water has shown great potential. In the PEC process, the application of a small external bias not only increases the separation and transfer efficiency of the photogenerated electron-hole pairs but also oxidizes the organic compounds electrochemically [16-18]. Therefore, PEC has been widely applied for the removal of organic compounds because of the synergism between photocatalysis and electrocatalysis.

$\mathrm{BiPO}_{4}$ was first reported as a photocatalyst in $2010[19,20]$. This compound has a higher photocatalytic activity than $\mathrm{TiO}_{2}$ and is a promising UV-responsive photocatalyst. However, the $\mathrm{BiPO}_{4}$ photocatalyst powder prepared by the conventional method has a low surface area [21], and the photocatalytic efficiency is limited in practice. In addition, the separation of the powdered photocatalyst after use is difficult, and its recyclability is poor. Zhang's group deposited $\mathrm{BiPO}_{4}$ on fluorine-doped tin oxide (FTO) glass, which increased the contact area between the catalyst and liquid pollutants $[22,23]$. Thus, the PEC degradation of the organic compounds was increased compared with photocatalytic oxidation using the components separately. Furthermore, the $\mathrm{BiPO}_{4} / \mathrm{FTO}$ electrode is more stable and solid-liquid separation is easier. However, $\mathrm{BiPO}_{4}$ has a large band gap ( $3.8 \mathrm{eV})$, meaning that is responsive to ultraviolet light $[19,24]$. Thus, the utilization of solar energy is relatively low, limiting the catalytic efficiency. The combination of Bi$\mathrm{PO}_{4}$ with a visible-light-responsive semiconductor to form a heterojunction is an efficient method to increase the light absorption range and improve the photocatalytic activity. To date, the coupling of $\mathrm{BiPO}_{4}$ with compounds such as $\mathrm{BiVO}_{4}$ [25], $\mathrm{AgBr}$ [26], $\mathrm{BiOBr}$ [27], and g- $\mathrm{C}_{3} \mathrm{~N}_{4}$ [28] has been reported to result in excellent photocatalytic activity in the visible region.

$\mathrm{BiOI}$ is a typical visible light catalyst with a narrow band gap and a large light absorption range [29-33]. Many researchers have used the light absorption properties of BiOI to modify $\mathrm{TiO}_{2}[34,35], \mathrm{BiOCl}[36,37], \mathrm{ZnO}[38]$, and other catalysts to form $\mathrm{p}$-n heterojunctions, thus improving their light absorption properties and photocatalytic performance [39-42]. Powdered p-n $\mathrm{BiPO}_{4} / \mathrm{BiOI}$ composite catalysts with excellent visible light photocatalytic activity have been reported [43-45]. Considering the shortcomings of powdered photocatalysts, a composite electrode might be a more successful wastewater treatment method. To date, a BiOI/BiPO ${ }_{4}$ film electrode for the PEC-based degradation of organic compounds has not been reported. Thus, the method of fabrication and the properties of the composite electrode should be studied in detail.

In this work, we used a simple two-step electrodeposition method to fabricate a $\mathrm{BiOI} / \mathrm{BiPO}_{4}$ film electrode. The prepared $\mathrm{BiOI} / \mathrm{BiPO}_{4} / \mathrm{FTO}$ composite film electrode has a p-n junction structure, which enhances visible light absorption and improves the electron-hole transfer efficiency. The BiOI/BiPO 4 /FTO composite film electrode exhibits higher PEC oxidation ability than the pure BiOI/FTO and $\mathrm{BiPO}_{4} / \mathrm{FTO}$ film electrodes. The effects of the working voltage and electrode deposition time, as well as other factors, on the removal of tetracycline were studied systematically. Finally, the mechanism for the PEC oxidation of organic compounds by the BiOI/BiPO $/$ FTO composite film electrode is discussed.

\section{Experimental}

\subsection{Preparation of materials}

All chemicals were of analytical grade. The electrochemical deposition experiment was carried out using a CHI760e electrochemical workstation. The resistance of the FTO glass was $15 \Omega$. The FTO glass was washed in ethanol and $10 \%$ nitric acid for $30 \mathrm{~min}$ with ultrasonication. Then, the glass was thoroughly washed with ethanol and distilled water several times. Subsequently, it was dried at $60{ }^{\circ} \mathrm{C}$ for $12 \mathrm{~h}$. The $\mathrm{BiPO}_{4}$ precursor electrolyte solution was prepared as follows. $10 \mathrm{mmol} / \mathrm{L}$ of ethylenediaminetetraacetic acid (EDTA) was dissolved in 100 mL distilled water. Then, $10 \mathrm{mM}$ of $\mathrm{Bi}\left(\mathrm{NO}_{3}\right)_{3} \cdot 5 \mathrm{H}_{2} \mathrm{O}$ was added dropwise to the EDTA solution, and the $\mathrm{pH}$ was adjusted to 1 using concentrated $\mathrm{HNO}_{3}$. Subsequently, $100 \mathrm{mmol} / \mathrm{L}$ of $\mathrm{Na}_{3} \mathrm{PO}_{4} \cdot 12 \mathrm{H}_{2} \mathrm{O}$ and $50 \mathrm{~mL}$ of $30 \% \mathrm{H}_{2} \mathrm{O}_{2}$ were added dropwise to the above solution ( $\mathrm{pH}=1)$, which was then stirred for about 30 min to obtain a homogeneous solution. The electrodeposition method was used to prepare $\mathrm{BiPO}_{4} / \mathrm{FTO}$ electrode in a three-electrode system. The modified FTO glass was the working electrode and was rinsed with distilled water before electrodeposition. A Pt wire was used as the counter electrode, and a saturated calomel electrode (SCE) was used as the reference electrode. The $\mathrm{BiPO}_{4} / \mathrm{FTO}$ electrode material was obtained by electrodeposition at a bias of $-0.15 \mathrm{~V}$ for $45 \mathrm{~min}$.

The BiOI precursor electrolyte solution was prepared as follows. $0.04 \mathrm{~mol} / \mathrm{L} \mathrm{Bi}\left(\mathrm{NO}_{3}\right)_{3} \cdot 5 \mathrm{H}_{2} \mathrm{O}$ and $0.4 \mathrm{~mol} / \mathrm{L} \mathrm{KI}$ were dissolved in $50 \mathrm{~mL}$ of distilled water, and the $\mathrm{pH}$ was adjusted to 1.7 by adding $\mathrm{HNO}_{3}$. Then, the solution was mixed with $20 \mathrm{~mL}$ of absolute ethanol (100\%) containing $0.23 \mathrm{~mol} / \mathrm{L}$ $p$-benzoquinone. A Pt wire was used as the counter electrode, and an SCE was used as the reference electrode. The prepared $\mathrm{BiPO}_{4} / \mathrm{FTO}$ electrode was the working electrode. A series of the $\mathrm{BiOI} / \mathrm{BiPO}_{4} / \mathrm{FTO}$ electrode materials were obtained by controlling the electrodeposition time of BiOI (30-180 s) at a bias voltage of $-0.6 \mathrm{~V}$. These samples are denoted BiOI/BiPO 4 /FTO-30s, $\quad \mathrm{BiOI} / \mathrm{BiPO}_{4} / \mathrm{FTO}_{-60 s}, \quad \mathrm{BiOI} / \mathrm{BiPO}_{4} / \mathrm{FTO}_{-90 \mathrm{~s}}$, $\mathrm{BiOI} / \mathrm{BiPO}_{4} / \mathrm{FTO}_{-120 s,} \mathrm{BiOI} / \mathrm{BiPO}_{4} / \mathrm{FTO}_{-150 s}$, and $\mathrm{Bi}-$

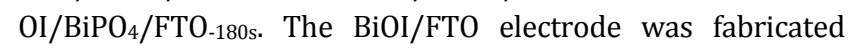
under the same conditions using FTO as the substrate.

\subsection{Characterization}

X-ray diffractometry (XRD, Bruker D8 Advance, $\mathrm{Cu} K_{\alpha}, \lambda=$ $1.5406 \AA, 40 \mathrm{kV}, 40 \mathrm{~mA}$ ) analysis of the electrode material was carried out at room temperature in a scanning range of $10^{\circ}-70^{\circ}$. Morphological characterization of the catalytic material was carried out using field-emission scanning electron microscopy (FE-SEM, SU8010) at an acceleration voltage of 100 $\mathrm{kV}$. Transmission electron microscopy (TEM, JEM 2100F) images were obtained at an acceleration voltage of $200 \mathrm{kV}$. The UV-vis diffuse reflectance spectra (DRS) of the electrodes were recorded on an UV-vis spectrophotometer (U-3010, Hitachi) 
equipped with an integrating sphere, and $\mathrm{BaSO}_{4}$ was used as the reference. Photoluminescence (PL) spectra of the electrodes were obtained by fluorescence spectrometry (FLS980, Edinburgh Instruments, UK) with an excitation wavelength of $245 \mathrm{~nm}$. X-ray photoelectron spectroscopy (XPS) analysis was carried out using an XPS spectrometer (PHI XPS Quantera II) equipped with a monochromatic $\mathrm{Al} K_{\alpha} \mathrm{X}$-ray source $(h v=$ $1486.6 \mathrm{eV}$ ).

\subsection{Performance tests}

The PEC performance of the materials was analyzed using an electrochemical workstation (CHI760E, Shanghai, China) with a Pt wire as the counter electrode and a SCE as the reference electrode. The BiOI/BiPO $4 /$ FTO electrode was the working electrode in the three-electrode system. The model organic pollutant was tetracycline $(100 \mathrm{~mL})$. The light source was a xenon lamp (Perfect Light) with an output intensity of $500 \mathrm{~W}$. The area of the $\mathrm{BiOI} / \mathrm{BiPO}_{4} / \mathrm{FTO}$ electrode material was $5 \mathrm{~cm}^{2}$. The concentration of tetracycline solution was determined at an absorption wavelength of $375 \mathrm{~nm}$ using a UV-visible spectrophotometer (U-3900, Hitachi). Photocurrent transient responses and electrochemical impedance spectroscopy (EIS) measurements were carried out on the same three-electrode electrochemical workstation with a $\mathrm{Na}_{2} \mathrm{SO}_{4}$ electrolyte solution (0.1 mol/L).

\section{Results and discussion}

\subsection{Structural and properties analysis}

The SEM images of the $\mathrm{BiPO}_{4} / \mathrm{FTO}, \mathrm{BiOI} / \mathrm{FTO}$, and Bi$\mathrm{OI} / \mathrm{BiPO}_{4} / \mathrm{FTO}$ electrodes are shown in Fig. 1. As shown in Fig. 1(a), a large number of $\mathrm{BiPO}_{4}$ nanorods with lengths of 1-2 $\mu \mathrm{m}$ and diameters of 400-600 nm were deposited on the FTO glass substrate. As shown by the image of the pure deposited BiOI in Fig. 1(b), the uniform BiOI nanosheets were directly electrodeposited on the FTO glass substrate. The images of Bi$\mathrm{OI} / \mathrm{BiPO}_{4} / \mathrm{FTO}$ composite electrode (Figs. 1(c)-(f)) show that $2 \mathrm{D} \mathrm{BiOI}$ nanosheets grew on the surface of the $1 \mathrm{D} \mathrm{BiPO}_{4}$ nanorods. When the BiOI deposition time was $90 \mathrm{~s}$ (Fig. 1(c)), the BiOI nanosheets aggregated together, forming flower-like BiOI structures. As the deposition time increased from 90 to $150 \mathrm{~s}$, the flower structures gradually disappeared and nanosheets

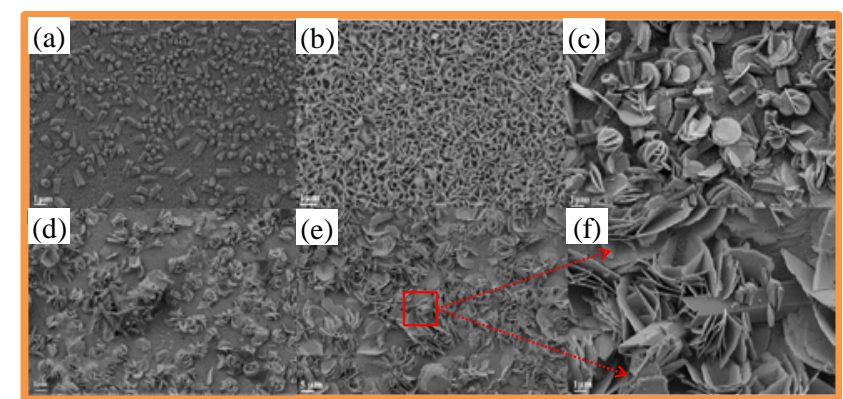

Fig. 1. SEM images of the $\mathrm{BiPO}_{4}(\mathrm{a}), \mathrm{BiOI}$ (b), and $\mathrm{BiOI} / \mathrm{BiPO}_{4} / \mathrm{FTO}$ (c-f) electrodes prepared with different BiOI deposition times. (c) $90 \mathrm{~s}$; (d) $120 \mathrm{~s}$; (e, f) $150 \mathrm{~s}$. appeared (Figs. 1(e) and (f)).

Powder XRD patterns of the prepared $\mathrm{BiOI} / \mathrm{BiPO}_{4} / \mathrm{FTO}$ electrodes were obtained to identify the crystal phases. As shown in Fig. 2, the (100), (101), (110), (111), (200), and (102) Bragg peaks of $\mathrm{BiPO}_{4}$ were observed, corresponding to hexagonal $\mathrm{BiPO}_{4}$ (JCPDS 15-0766). The characteristic (002), (102), (110), and (004) peaks are consistent with tetragonal BiOI (JCPDS 00-010-0445). These characteristic peaks of $\mathrm{BiPO}_{4}$ and BiOI were observed in the XRD pattern of the BiOI/BiPO 4 /FTO composite electrode, suggesting the successful preparation of the $\mathrm{BiOI} / \mathrm{BiPO}_{4} / \mathrm{FTO}$ composite electrode.

TEM was used to investigate the crystal structure and morphologies of the $\mathrm{BiOI} / \mathrm{BiPO}_{4} / \mathrm{FTO}_{-150 \text { s }}$ electrode material further (Fig. 3). Figs. 3(a) and (b) show that the BiOI nanosheets were successfully loaded onto the $\mathrm{BiPO}_{4}$ nanorods. In Figs. 3(c) and (d), several lattice stripes with lattice distances of $0.349,0.606$, 0.267 , and $0.282 \mathrm{~nm}$ can be clearly seen, and these can be attributed to the (110) and (100) crystal planes of hexagonal $\mathrm{BiPO}_{4}$ and the (111) and (110) crystal planes of tetragonal BiOI, respectively. The results suggest that the p-n heterojunction of the BiOI/BiPO $/$ FTO composite electrode had been successfully prepared by the two-step electrodeposition method, which is consistent with the XRD characterization of the BiOI/BiPO 4 /FTO electrode materials. Energy dispersive X-ray (EDX) spectroscopy measurements of the $\mathrm{BiOI} / \mathrm{BiPO}_{4} / \mathrm{FTO}_{-150}$ composite electrode and the corresponding EDX mappings are shown in Fig. 3. Only $\mathrm{Bi}, \mathrm{O}$, I, and $\mathrm{P}$ are present in the BiOI/BiPO $/$ FTO-150s $_{1}$ composite electrode, and these elements are uniformly distributed.

XPS measurements were used to investigate the surface chemical states of the $\mathrm{BiPO}_{4} / \mathrm{FTO}, \mathrm{BiOI} / \mathrm{FTO}$, and $\mathrm{Bi}$ -

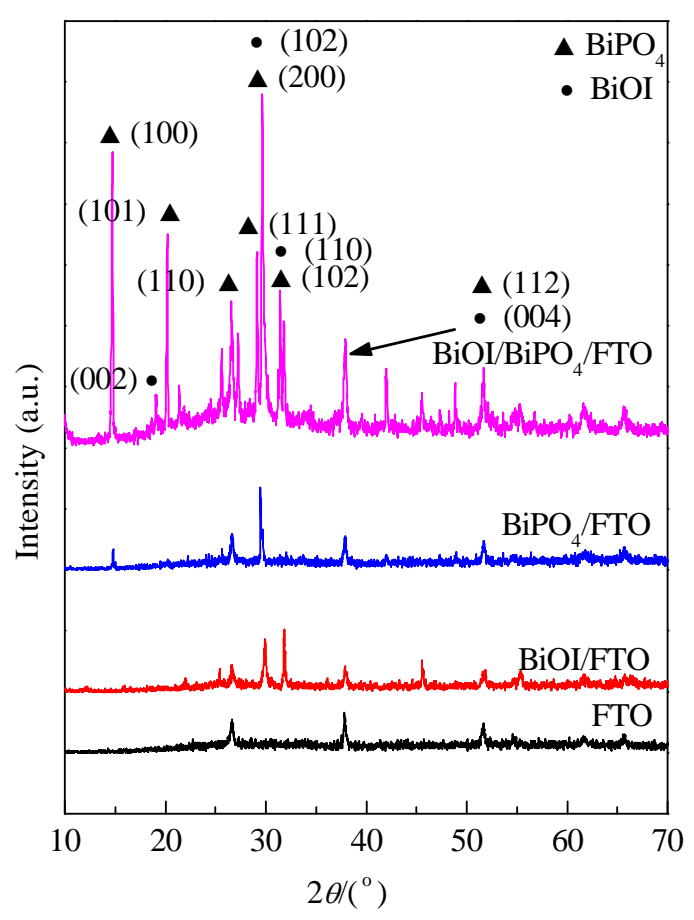

Fig. 2. XRD patterns of the pure $\mathrm{BiPO}_{4} / \mathrm{FTO}, \mathrm{BiOI} / \mathrm{FTO}$, and $\mathrm{Bi}$ $\mathrm{OI} / \mathrm{BiPO}_{4} / \mathrm{FTO}$ composite electrode. 

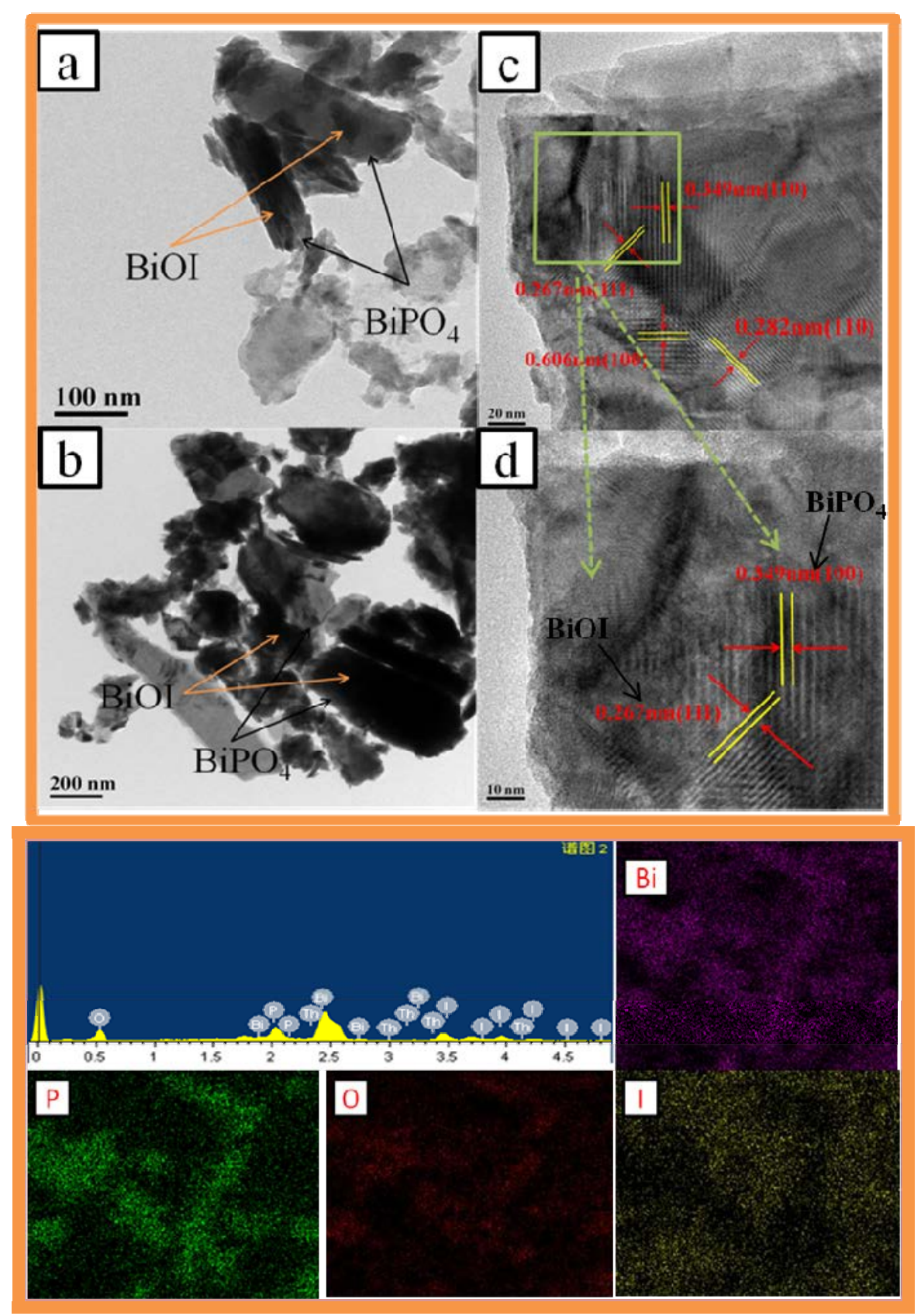

Fig. 3. TEM images of $\mathrm{BiOI} \mathrm{BiPO}_{4} / \mathrm{FTO}_{-150 \mathrm{~s}}(\mathrm{a}-\mathrm{d})$ and $\mathrm{EDX}$ elemental maps of $\mathrm{P}, \mathrm{Bi}, \mathrm{O}$, and I.

OI/BiPO 4 /FTO electrodes. As shown in the XPS survey spectra (Fig. 4(a)), I and P were both present in the BiOI/BiPO 4 /FTO electrode. The $\mathrm{P} 2 p$ peak is located at $132.25 \mathrm{eV}$ in the spectrum of the $\mathrm{BiOI} / \mathrm{BiPO}_{4} / \mathrm{FTO}$ electrode and at $131.87 \mathrm{eV}$ in the spectrum of the $\mathrm{BiPO}_{4} / \mathrm{FTO}$ electrode (Fig. 4(b)), indicating that $\mathrm{P}$ is present as $\mathrm{P}^{5+}$. The small shift to a higher binding energy of $\mathrm{P}^{5+}$ in the $\mathrm{BiOI} / \mathrm{BiPO}_{4} / \mathrm{FTO}$ electrode indicates that there is some interaction between $\mathrm{BiOI}$ and $\mathrm{BiPO}_{4}$. The binding energies of I $3 d_{5 / 2}(618.24 \mathrm{eV})$ and I $3 d_{3 / 2}(629.84 \mathrm{eV})$ in the spectrum of the $\mathrm{BiOI} / \mathrm{BiPO}_{4} / \mathrm{FTO}$ electrode are a little lower than those of the BiOI/FTO electrode (618.36 and $630.01 \mathrm{eV}$ ) and are characteristic of $\mathrm{I}^{-}$[46]. As shown in Fig. 4(d), the binding energies of 157.99 and $163.32 \mathrm{eV}$ in the spectrum of the $\mathrm{Bi}$ OI/BiPO 4 /FTO electrode correspond to Bi $4 f_{7 / 2}$ and $\mathrm{Bi} 4 f_{5 / 2}$ of
$\mathrm{Bi}^{3+}$. The binding energies of the $\mathrm{Bi}^{3+}$ peak in the spectra of the $\mathrm{BiOI} / \mathrm{FTO}$ and $\mathrm{BiOI} / \mathrm{BiPO}_{4} / \mathrm{FTO}$ electrodes are lower than those in the spectrum of the $\mathrm{BiPO}_{4} / \mathrm{FTO}$ electrode. The decrease in the binding energy of $\mathrm{Bi}^{3+}$ in $\mathrm{BiPO}_{4}$ might be due to electron transfer from $\mathrm{BiOI}$ to $\mathrm{BiPO}_{4}$, which would increase the electron cloud density in the outer layer of $\mathrm{BiPO}_{4}$. Correspondingly, the electron cloud density of BiOI would decrease, resulting in an increase in the band energy of $\mathrm{Bi}^{3+}$ in $\mathrm{BiOI}$. The XPS results further demonstrate the coexistence of $\mathrm{BiPO}_{4}$ and $\mathrm{BiOI}$ in the as-prepared $\mathrm{p}-\mathrm{n}$ heterojunction electrode.

Fig. 5 shows the UV-vis DRS of BiOI/FTO, $\mathrm{BiPO}_{4} / \mathrm{FTO}$, and $\mathrm{BiOI} / \mathrm{BiPO}_{4} / \mathrm{FTO}$ electrodes. $\mathrm{BiPO}_{4}$ shows absorption in the ultraviolet region with an absorption edge at about $360 \mathrm{~nm}$. Although pure BiOI exhibits strong visible light absorption with 

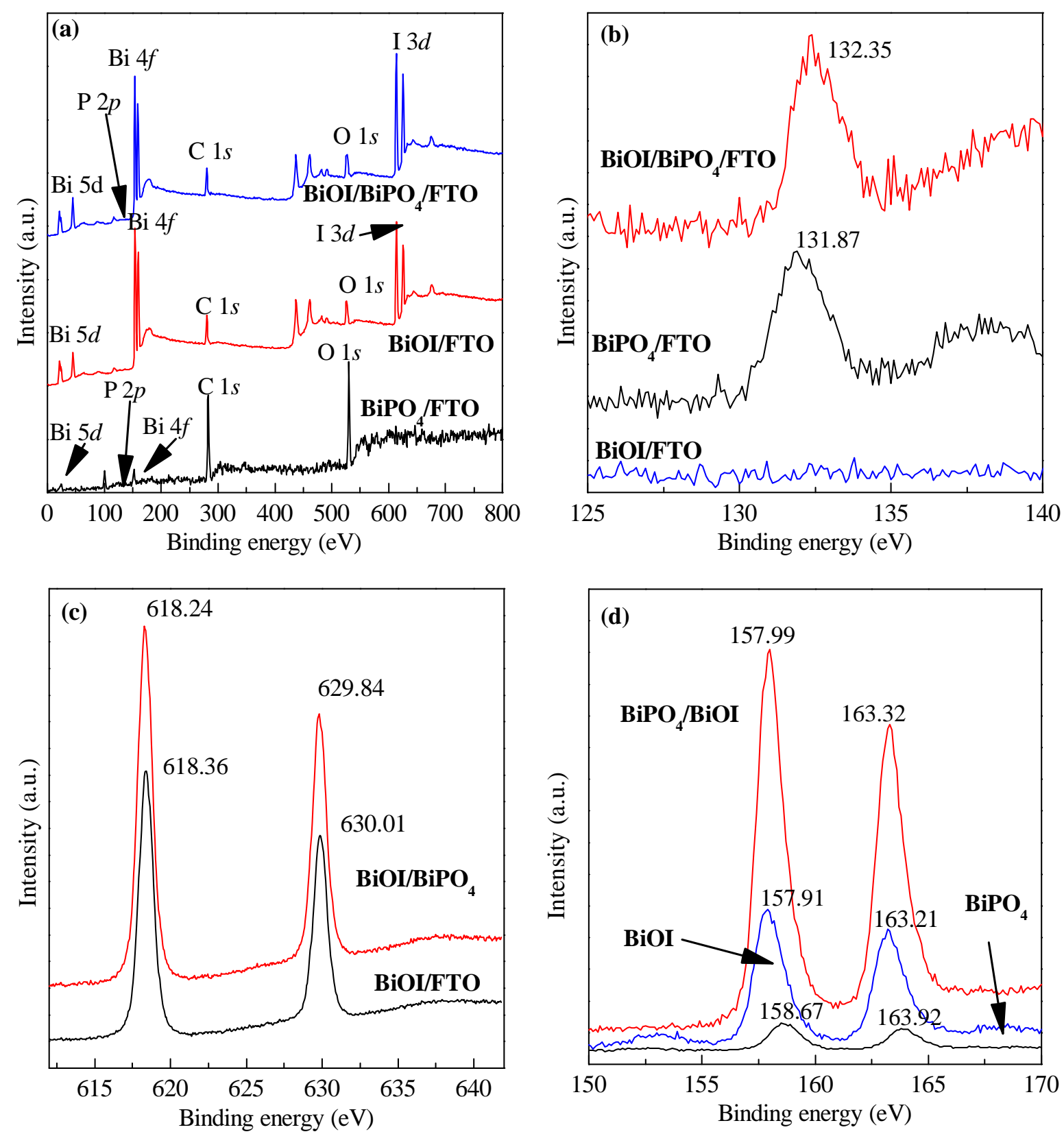

Fig. 4. XPS spectra of $\mathrm{BiPO}_{4} / \mathrm{FTO}$, pure BiOI/FTO, and BiOI/BiPO $/$ FTO electrodes. (a) Survey; (b) P 2p; (c) I 3d; (d) Bi 4f.

an absorption edge at about $635 \mathrm{~nm}$. Compared with the pure $\mathrm{BiPO}_{4}$ nanorods and $\mathrm{BiOI}$ nanosheets, the light absorption ability of the $\mathrm{BiOI} / \mathrm{BiPO}_{4} / \mathrm{FTO}$ electrode from 250 to $600 \mathrm{~nm}$ was increased, which improved the PEC performance.

\subsection{Photoelectrocatalytic performance}

Fig. 6 shows the PEC degradation performance of the Bi$\mathrm{OI} / \mathrm{BiPO}_{4} / \mathrm{FTO}$ electrodes prepared at different BiOI deposition times. The target pollutant was a tetracycline solution (10 ppm) containing $0.1 \mathrm{~mol} / \mathrm{L} \mathrm{Na}_{2} \mathrm{SO}_{4}$. In the static system, the tetracycline solution did not undergo self-degradation under illumination, so the effects of self-degradation can be excluded. The PEC degradation efficiency of the $\mathrm{BiOI} / \mathrm{BiPO}_{4} / \mathrm{FTO}$ elec- trode increased initially and then decreased with increasing BiOI deposition time (Fig. 6(a)). When the BiOI deposition time was $150 \mathrm{~s}, \mathrm{BiOI} / \mathrm{BiPO}_{4} / \mathrm{FTO}$ had the maximum PEC degradation efficiency. The corresponding reaction rate constants for tetracycline degradation using the $\mathrm{BiOI} / \mathrm{BiPO}_{4} / \mathrm{FTO}$ electrodes are shown in Fig. 6(b). For samples prepared at deposition times of less than BiOI $150 \mathrm{~s}$, the photocatalytic degradation rate of tetracycline increased gradually and subsequently began to decrease. The $\mathrm{BiOI} / \mathrm{BiPO}_{4} / \mathrm{FTO}_{-150 \text { s }}$ electrode, which was prepared at a deposition time of $150 \mathrm{~s}$, has the best reaction rate constant ( $k=0.35 \mathrm{~h}^{-1}$ ), indicating that abundant BiOI inhibits the photoelectrocatalytic degradation efficiency.

Fig. 7 shows a comparison of the PEC degradation of tetracycline of the $\mathrm{BiOI} / \mathrm{BiPO}_{4} / \mathrm{FTO}_{-150 s}$, $\mathrm{BiPO}_{4} / \mathrm{FTO}$, and BiOI/FTO 


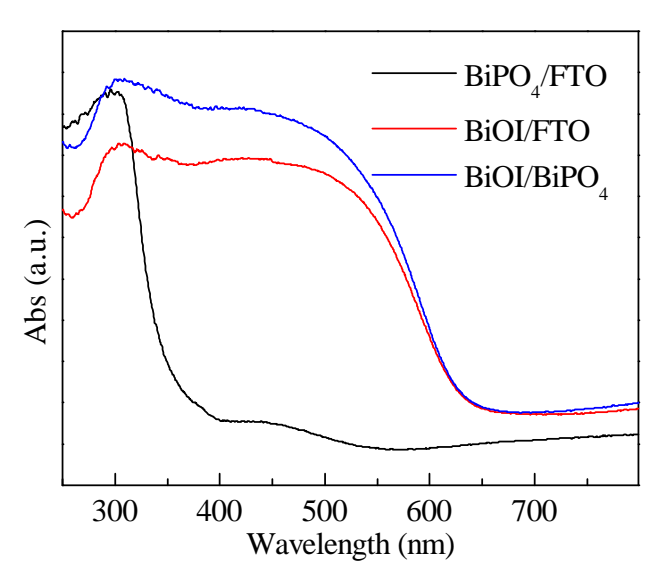

Fig. 5. The UV-vis DRS of the bare $\mathrm{BiPO}_{4} / \mathrm{FTO}$, pure $\mathrm{BiOI} / \mathrm{FTO}$, and Bi$\mathrm{OI} / \mathrm{BiPO}_{4} / \mathrm{FTO}$ electrodes.

electrodes. As shown in Fig. 7(a), the BiOI/BiPO $4 / \mathrm{FTO}_{-150 \text { s }}$ electrode has a higher PEC activity than the BiOI/FTO and Bi$\mathrm{PO}_{4} /$ FTO electrodes at an applied working bias $(E)$ of $1.2 \mathrm{eV}$, the PEC degradation efficiency of which reached nearly $80 \%$ in $4 \mathrm{~h}$. The reaction rate constant $(k)$ of the $\mathrm{BiOI} / \mathrm{BiPO}_{4} / \mathrm{FTO}_{-150}$ electrode is $0.386 \mathrm{~h}^{-1}$, which is 1.98 times and 2.46 times higher than those of the BiOI/FTO and $\mathrm{BiPO}_{4} / \mathrm{FTO}$ electrodes, respectively. The experimental results show that the formation of the $\mathrm{BiOI} / \mathrm{BiPO}_{4}$ composite film greatly improved the photoelectrocatalytic activity of the $\mathrm{BiPO}_{4} / \mathrm{FTO}$ electrode.

The photocatalytic, electrocatalytic, and photoelectrocata-

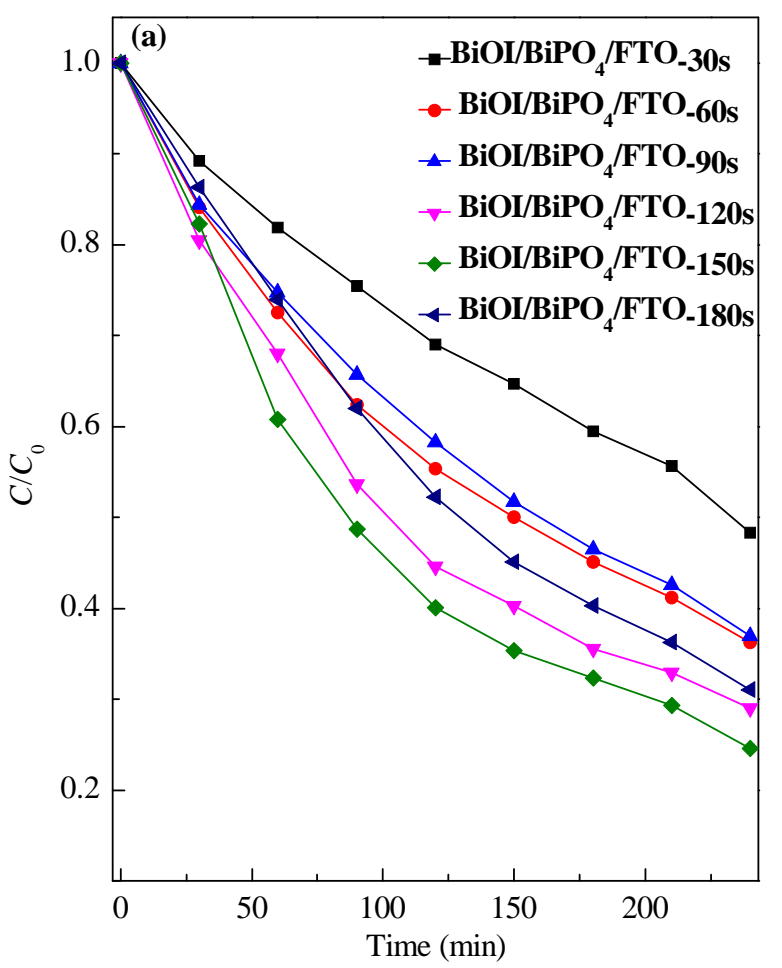

lytic degradation performances of tetracycline by the $\mathrm{Bi}$ $\mathrm{OI} / \mathrm{BiPO}_{4} / \mathrm{FTO}_{-150 \text { s }}$ electrode were compared to verify the synergistic effect of the $\mathrm{BiOI} / \mathrm{BiPO}_{4} / \mathrm{FTO}_{-150 s}$ electrode. As shown in Fig. 8(a), the BiOI/BiPO $/$ FTO $_{-150 \text { s }}$ electrode had photocatalytic and electrocatalytic degradation efficiencies of only $25 \%$ and $26 \%$, respectively, for tetracycline after $4 \mathrm{~h}$. In contrast, the PEC removal rate of tetracycline over the $\mathrm{BiOI} / \mathrm{BiPO} / \mathrm{FTO}_{-150 \mathrm{~s}}$ electrode reached $77 \%$, which is much greater than the electrocatalytic and photocatalytic removal rates. As shown in Fig. 8(b), the photoelectrocatalytic rate constant $(k)$ of the Bi-

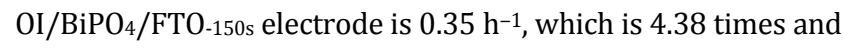
4.12 times higher than the photocatalytic and electrocatalytic degradation rate constants, respectively. The kinetic study also shows that the pollutant removal rate for the BiOI/BiPO $4 /$ FTO electrode is significantly higher in the photoelectrocatalytic process compared to the photocatalytic and electrocatalytic processes, suggesting that the catalyst benefits from the synergism of the photocatalytic and electrocatalytic degradation processes for the removal of organic compounds.

The applied bias potential can improve the separation of the photogenerated electron-hole pairs and enhance the PEC efficiency significantly. The effect of the working voltage (0.8-1.4 $\mathrm{V})$ on the PEC efficiency of the $\mathrm{BiOI} / \mathrm{BiPO}_{4} / \mathrm{FTO}_{-150 \text { s }}$ electrode was investigated, and the results are shown in Fig. 9. With increasing voltage, the removal rate and reaction rate constant $(k)$ of tetracycline initially increased and then decreased. At an applied voltage of $1.2 \mathrm{~V}$, the $\mathrm{BiOI} / \mathrm{BiPO}_{4} / \mathrm{FTO}_{-150 \text { s }}$ electrode had the highest tetracycline removal rate, indicating that $1.2 \mathrm{~V}$ is the optimum applied working voltage.

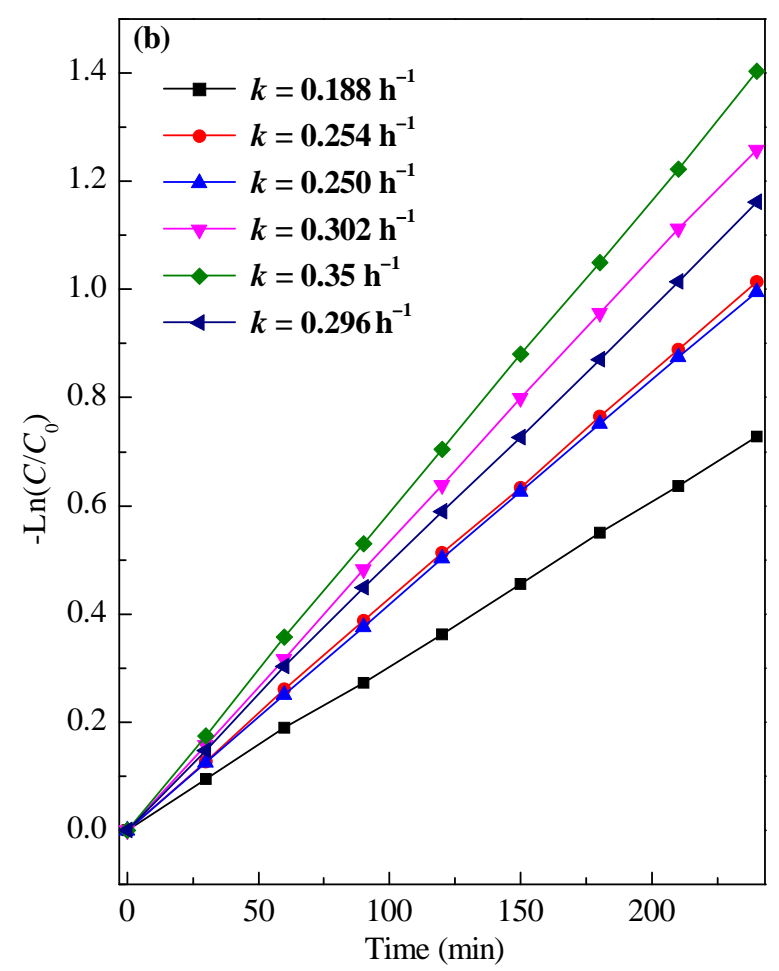

Fig. 6. (a) Photoelectron synergistic catalytic efficiency of the $\mathrm{BiOI} / \mathrm{BiPO}_{4} / \mathrm{FTO}$ electrode prepared at different BiOI deposition times; (b) the corresponding kinetic plots. 

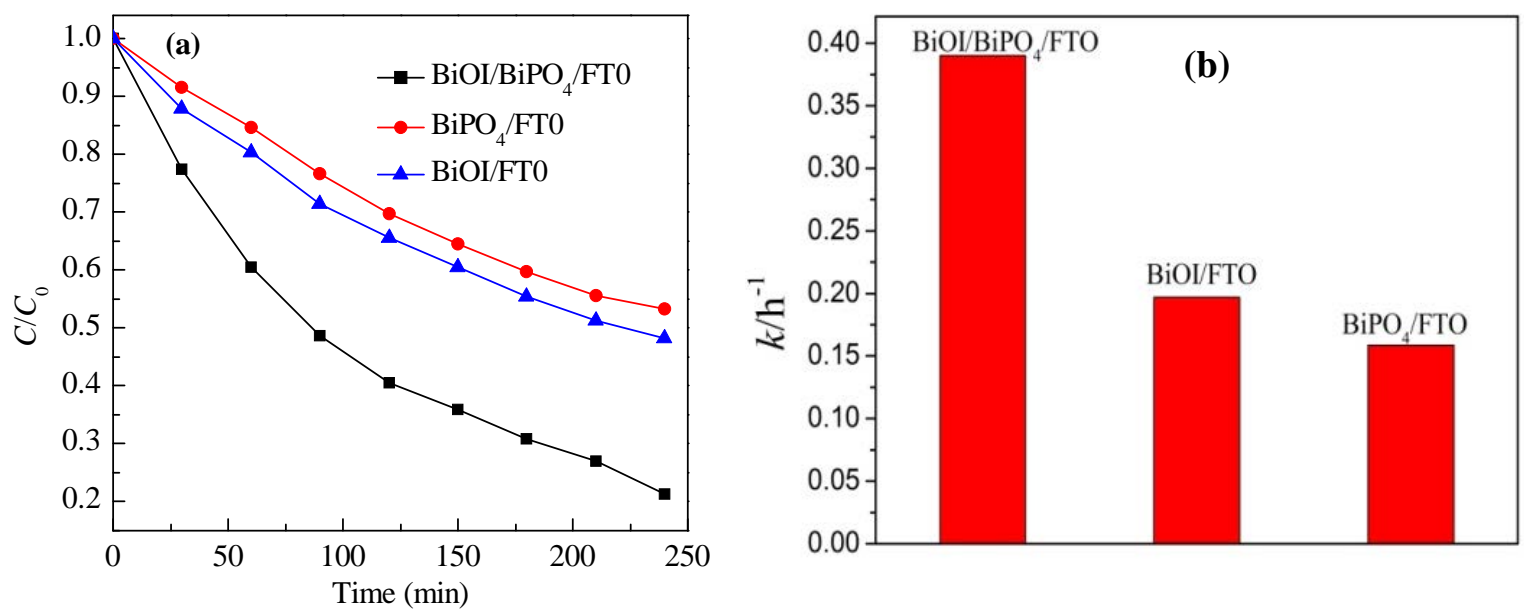

Fig. 7. (a) The photoelectrocatalytic activity of $\mathrm{BiPO}_{4} / \mathrm{FTO}$, BiOI/FTO, and $\mathrm{BiOI} / \mathrm{BiPO}_{4} / \mathrm{FTO}$; (b) the corresponding reaction rate constants under an applied operating bias of $1.2 \mathrm{eV}$.
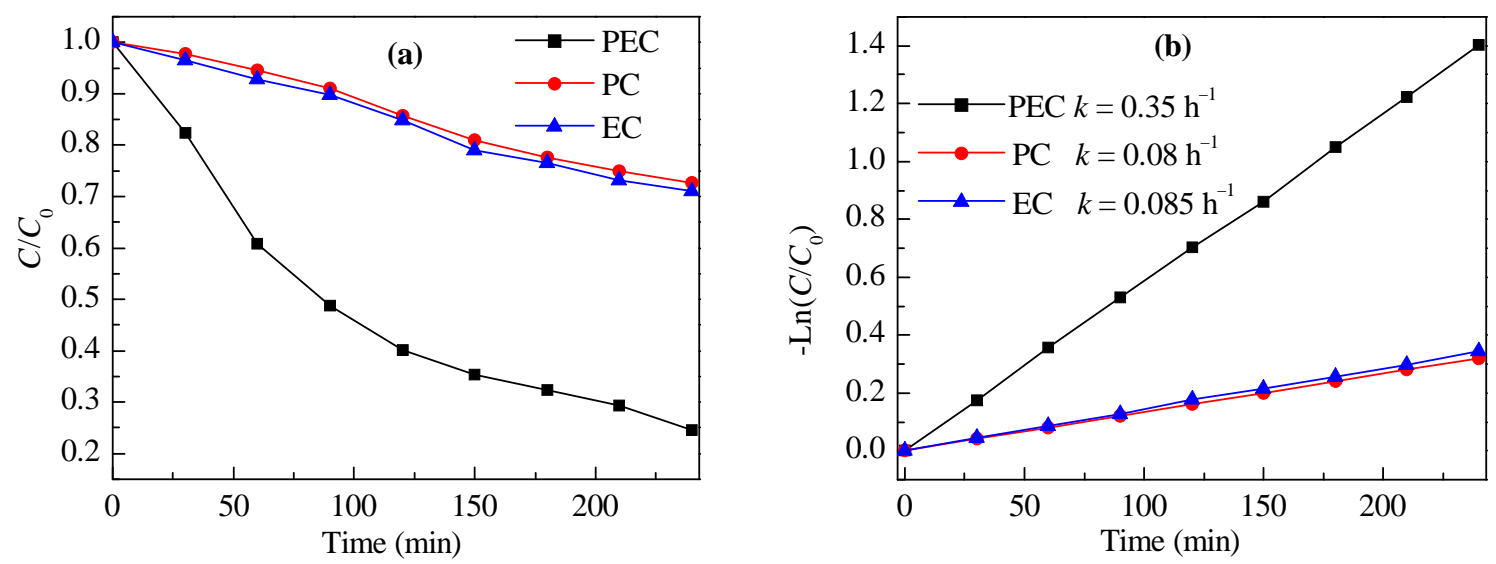

Fig. 8. (a) Photocatalytic, electrocatalytic, and photoelectrocatalytic degradation of tetracycline by the $\mathrm{BiOI} / \mathrm{BiPO}_{4} / \mathrm{FTO}_{-150 \text { s }}$ electrode; (b) kinetic plots and reaction rate constants.

\subsection{Mechanism of photoelectrocatalytic performance enhancement}

The transient photocurrent responses and EIS Nyquist plots of the $\mathrm{BiOI} / \mathrm{BiPO}_{4} / \mathrm{FTO}, \mathrm{BiOI} / \mathrm{FTO}$, and $\mathrm{BiPO}_{4} / \mathrm{FTO}$ electrodes

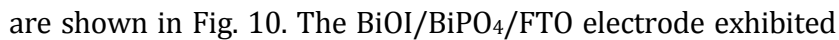
the strongest photocurrent response: $2.5 \times 10^{-5} \mathrm{~A}$, which is twice that of the bare BiOI electrode and nearly 20 times that of the $\mathrm{BiPO}_{4}$ electrode alone. This result indicates that the electron-hole separation efficiency was greatly improved. The Nyquist plots in Fig. 10 (b) show that the BiOI/BiPO 4 /FTO electrode has a smaller arc than those of the BiOI/FTO and Bi$\mathrm{PO}_{4}$ /FTO electrodes. This means that the BiOI/BiPO $/$ FTO electrode has better electron-hole separation because of the formation of the p-n heterojunction between $p$-BiOI and $\mathrm{n}-\mathrm{BiPO}_{4}$. The results are consistent with the comparative photoelectrocatalytic degradation experiments for the $\mathrm{BiPO}_{4} / \mathrm{FTO}$, BiOI/FTO, and BiOI/BiPO 4 /FTO electrodes (Fig. 7).

Fig. 11 shows the transient photocurrent responses and
Nyquist plots of the $\mathrm{BiOI} / \mathrm{BiPO}_{4} / \mathrm{FTO}$ electrodes prepared at different deposition times. As shown in Fig. 11(a), with increasing BiOI deposition time, the photocurrent increased initially and then decreased, reaching a maximum at a deposition time of $150 \mathrm{~s}$. In addition, the Nyquist plot of the BiOI/BiPO $4 / \mathrm{FTO}_{-150 \text { s }}$ electrode has the smallest radius (Fig. 11(b)). These results show that the $\mathrm{BiOI} / \mathrm{BiPO}_{4} / \mathrm{FTO}-150$ s electrode has the highest separation efficiency of the tested samples. The photocurrent and electrochemical impedance trends for the $\mathrm{BiOI} / \mathrm{BiPO}_{4} / \mathrm{FTO}$ electrodes are consistent with the trend in photoelectrocatalytic degradation activity shown in Fig. 6. Thus, the Nyquist plots of the different BiOI/BiPO 4 /FTO electrodes further confirm their good photoelectrocatalytic activities.

Fig. 12 shows the PL of the $\mathrm{BiPO}_{4} / \mathrm{FTO}, \mathrm{BiOI} / \mathrm{FTO}$, and Bi$\mathrm{OI} / \mathrm{BiPO}_{4} / \mathrm{FTO}$ electrodes. A higher PL intensity indicates a higher recombination of photogenerated electron-hole pairs. The BiOI/ $/ \mathrm{BiPO}_{4} / \mathrm{FTO}$ electrode yielded a lower PL intensity than those of the BiOI/FTO and $\mathrm{BiPO}_{4} /$ FTO electrodes, showing that the recombination of photogenerated electron-hole pairs 

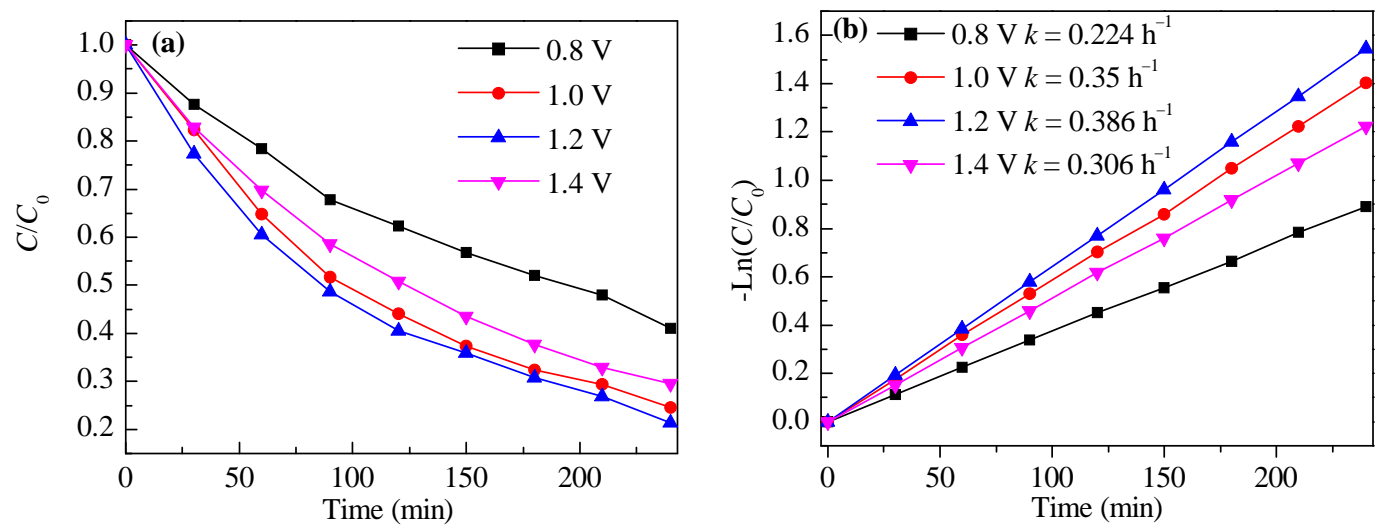

Fig. 9. (a) Photoelectrocatalytic degradation of tetracycline using the $\mathrm{BiOI} / \mathrm{BiPO}_{4} / \mathrm{FTO}_{-150 \text { s }}$ electrode at different applied voltages; (b) kinetic plots and reaction rate constants.
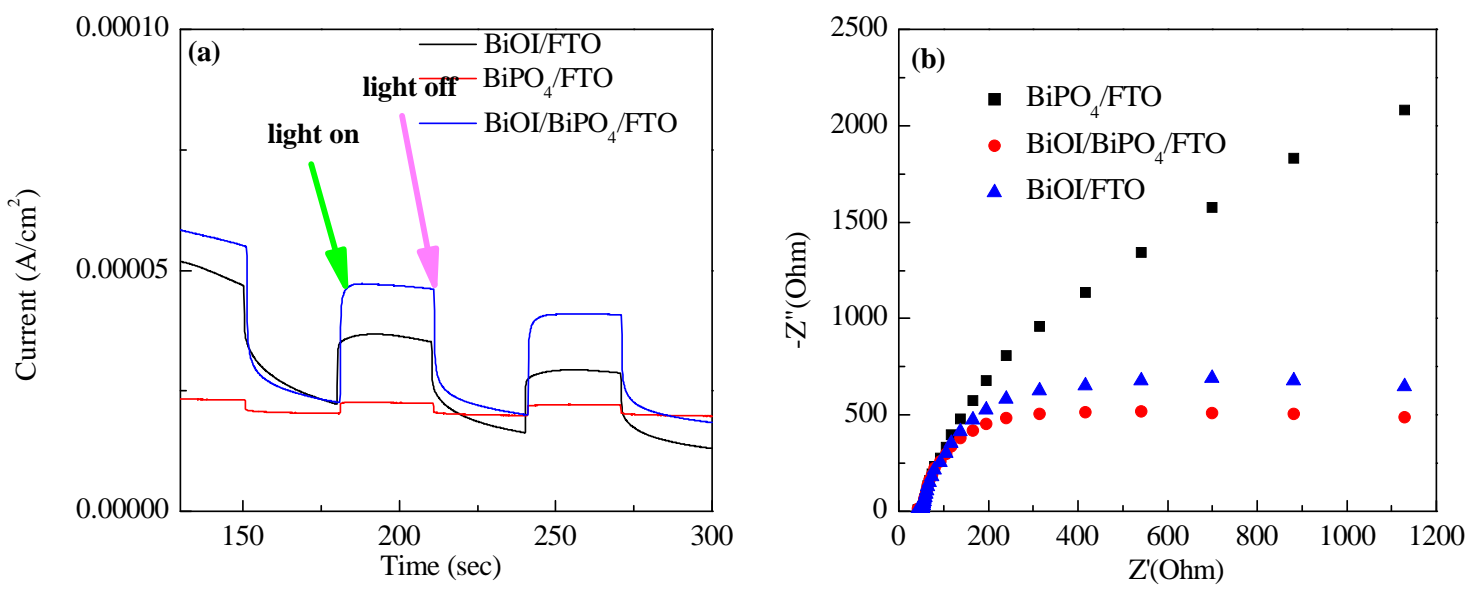

Fig. 10. (a) Transient photocurrent responses of the $\mathrm{BiPO}_{4} / \mathrm{FTO}$, $\mathrm{BiOI} / \mathrm{FTO}$, and $\mathrm{BiOI} / \mathrm{BiPO}_{4} / \mathrm{FTO}$ electrodes; (b) corresponding EIS Nyquist plots.
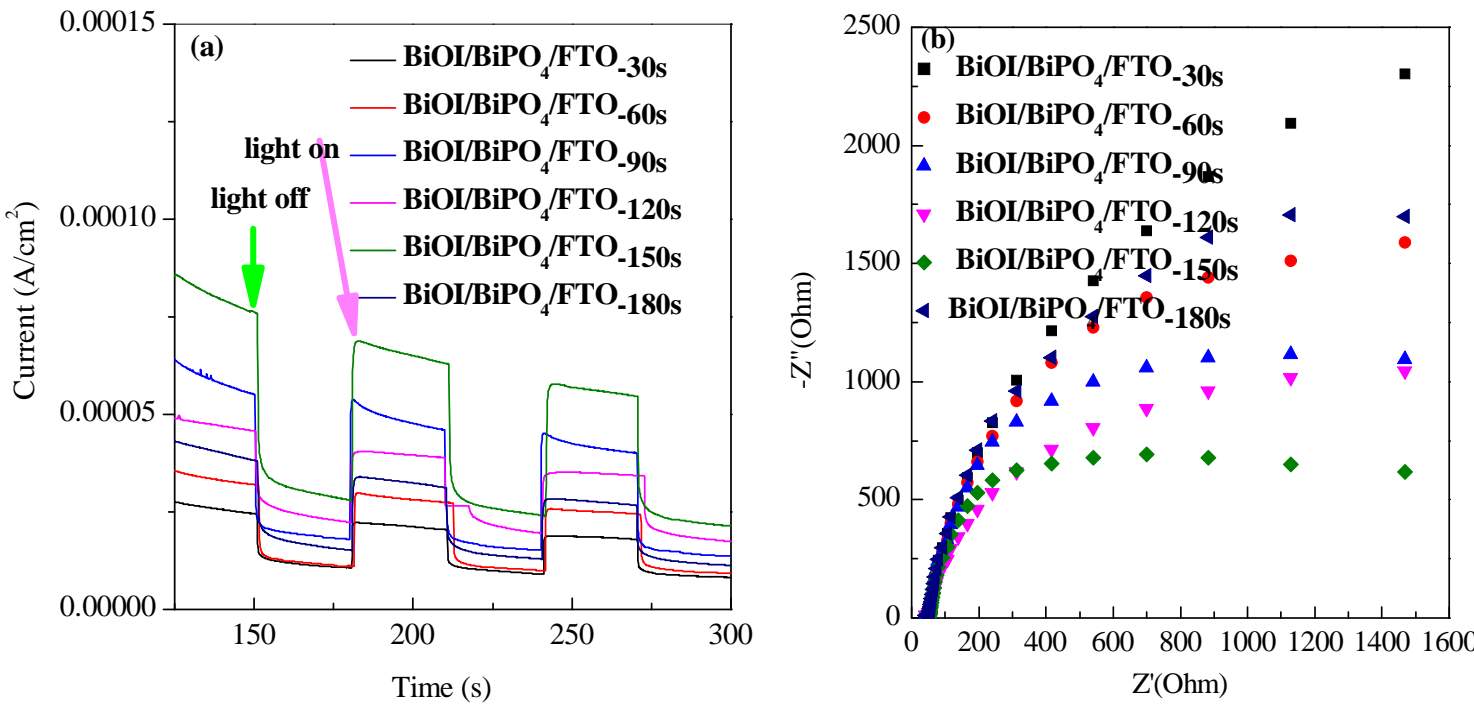

Fig. 11. (a) Transient photocurrent responses of different $\mathrm{BiOI} / \mathrm{BiPO}_{4} / \mathrm{FTO}$ electrodes; (b) the corresponding Nyquist plots.

was reduced in the $\mathrm{BiOI} / \mathrm{BiPO}_{4} / \mathrm{FTO}$ electrode.

Trapping experiments were carried out to identify the main active species in the PEC degradation process, and a possible mechanism of action was formulated. As shown in Fig. 13, when KI was used as a trapping agent for holes $\left(\mathrm{h}^{+}\right)$, the PEC removal efficiency of tetracycline over the $\mathrm{BiOI} / \mathrm{BiPO}_{4} / \mathrm{FTO}_{-150 \mathrm{~s}}$ electrode decreased only slightly, indicating that the holes $\left(\mathrm{h}^{+}\right)$ have little effect on the PEC degradation. In contrast, when ascorbic acid (vitamin C, VC) was used as a scavenger for the superoxide radical $\left(\cdot \mathrm{O}_{2}{ }^{-}\right)$, the PEC removal efficiency of the 


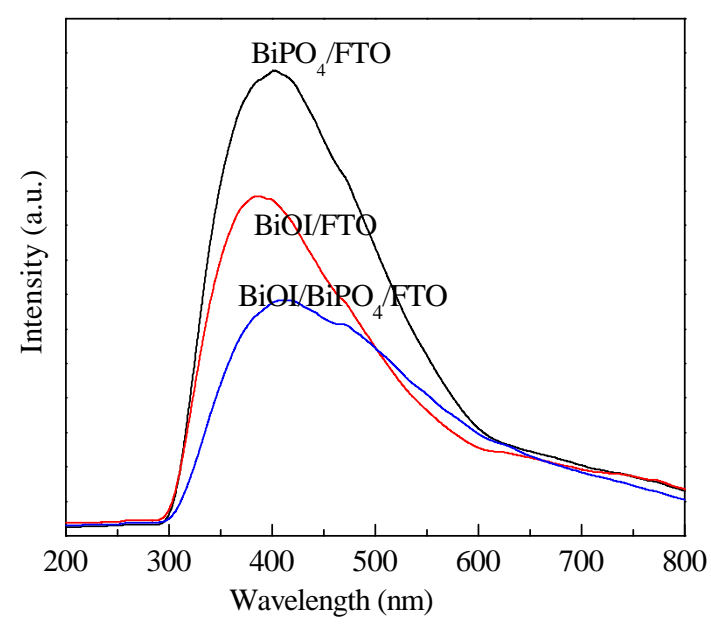

Fig. 12. PL spectra of the $\mathrm{BiOI} / \mathrm{BiPO}_{4} / \mathrm{FTO}, \mathrm{BiOI} / \mathrm{FTO}$, and $\mathrm{BiPO}_{4} / \mathrm{FTO}$ electrodes.

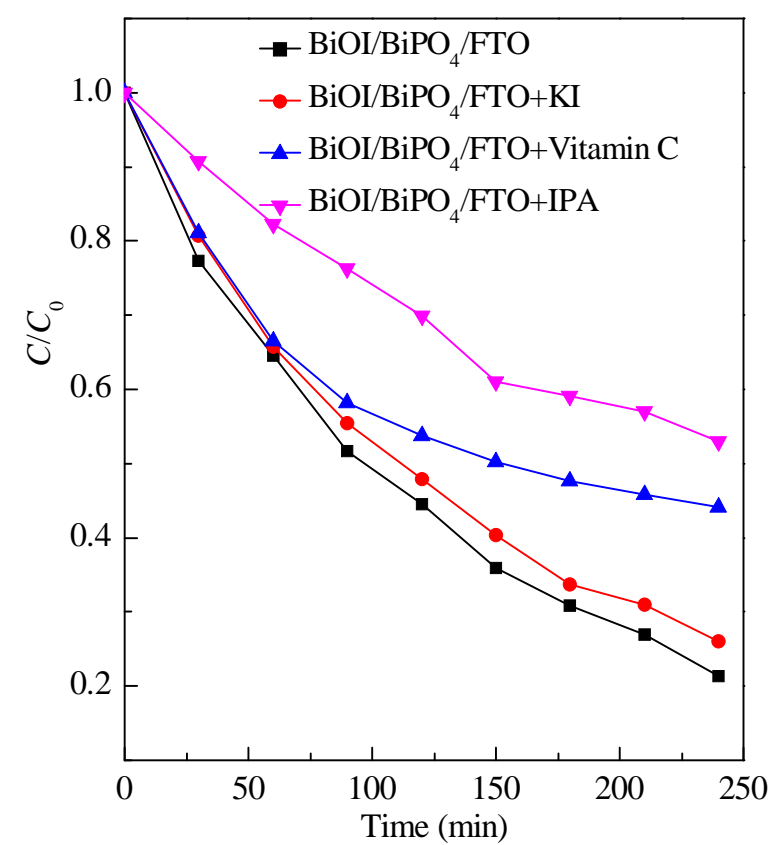

Fig. 13. Active species trapping experiments in the degradation of tetracycline using the $\mathrm{BiOI} / \mathrm{BiPO}_{4} / \mathrm{FTO}_{-150 \text { s }}$ electrode.

$\mathrm{BiOI} / \mathrm{BiPO}_{4} / \mathrm{FTO}_{-150 \text { s }}$ electrode decreased significantly, indicating that the superoxide radical $\left(\cdot \mathrm{O}_{2}{ }^{-}\right)$is an important active species and plays an crucial role in the photoelectrocatalytic reaction. In addition, when isopropanol (IPA) was used to trap hydroxyl radicals $(\bullet \mathrm{OH})$, the PEC removal efficiency also decreased significantly, indicating that the hydroxyl radical $(\bullet \mathrm{OH})$ is another important active species in the photoelectrocatalytic reaction. Thus, holes $\left(\mathrm{h}^{+}\right)$did not directly participate in the PEC degradation of tetracycline, and hydroxyl radicals $(\bullet \mathrm{OH})$ and superoxide radicals $\left(\bullet_{2}^{-}\right)$are the dominant species in the photoelectrocatalytic reaction.

The light absorption, surface reactions, and the separation of electron-hole pairs are the main determinants of the photocatalytic activity of a photocatalyst. In this paper, the p-n het-

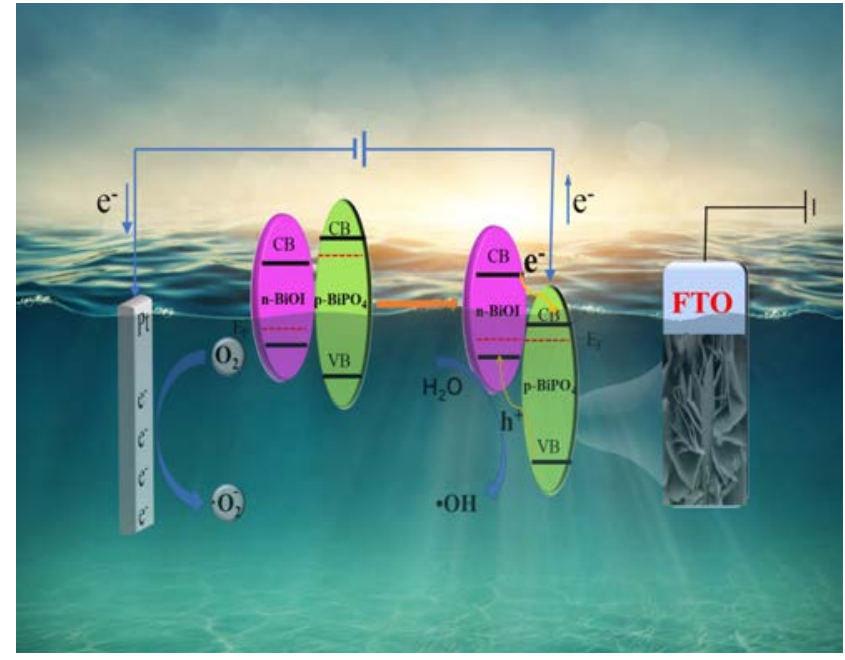

Fig. 14. Schematic of the degradation mechanism of the Bi$\mathrm{OI} / \mathrm{BiPO}_{4} / \mathrm{FTO}_{-150 \text { s }}$ electrode.

erojunctions formed by the 2D BiOI nanosheet and $1 \mathrm{D} \mathrm{BiPO}_{4}$ nanorod semiconductor play a leading role in the efficient separation of the photogenerated electron-hole pairs. For the BiOI/BiPO $/$ FTO composite electrode (Fig. 14), the conduction band of the p-type semiconductor (BiOI) moved up, whereas the conduction band of the n-type semiconductor $\mathrm{BiPO}_{4}$ moved down until the Fermi level reached equilibrium $[43,47,48]$. In addition, the conduction band of BiOI was higher than that of $\mathrm{BiPO}_{4}$. Thus, the transfer path of the electron-hole pairs was improved. On photoexcitation, the photogenerated electrons in the conduction band of $\mathrm{p}$-BiOI were transferred to that of $n$-BiPO ${ }_{4}$ effectively, subsequently rapidly moving to the platinum wire electrode through the external circuit under the action of the external bias. Finally, the photogenerated electrons transferred to the surface of the platinum wire reacted with oxygen and produced superoxide radicals $\left(\cdot \bullet_{2}{ }^{-}\right)$, which degraded the organic pollutants. At the same time, the corresponding holes transferred from the valence band of $n-\mathrm{BiPO}_{4}$ to that of $\mathrm{p}$-BiOI and reacted with water to produce hydroxyl radicals $(\bullet \mathrm{OH})$, which are the main active species in the photoelectrocatalytic reaction. Therefore, the fabrication of the p-n heterojunction structure promoted the separation and migration of the photogenerated charges, leading to the enhanced photoelectrocatalytic efficiency of the $\mathrm{BiPO}_{4} / \mathrm{FTO}$ electrode. Furthermore, the addition of the BiOI nanosheets greatly improved the visible light absorption and increased the light utilization of the photoelectrode, enhancing the photoelectrocatalytic activity.

\subsection{Stability of the $\mathrm{BiOI} / \mathrm{BiPO}_{4} / \mathrm{FTO}_{-150 \text { s }}$ electrode}

The $\mathrm{BiOI} / \mathrm{BiPO}_{4} / \mathrm{FTO}_{-150 \text { s }}$ electrode stability was evaluated by XRD measurements before and after photoelectrocatalytic and cycling experiments. The $\mathrm{BiOI} / \mathrm{BiPO}_{4} / \mathrm{FTO}_{-150 \text { s }}$ electrode showed excellent cycling stability for the PEC degradation of tetracycline (Fig. 15(a)). The photoelectrocatalytic degradation rate did not change after four 16 -h degradation cycles. As 

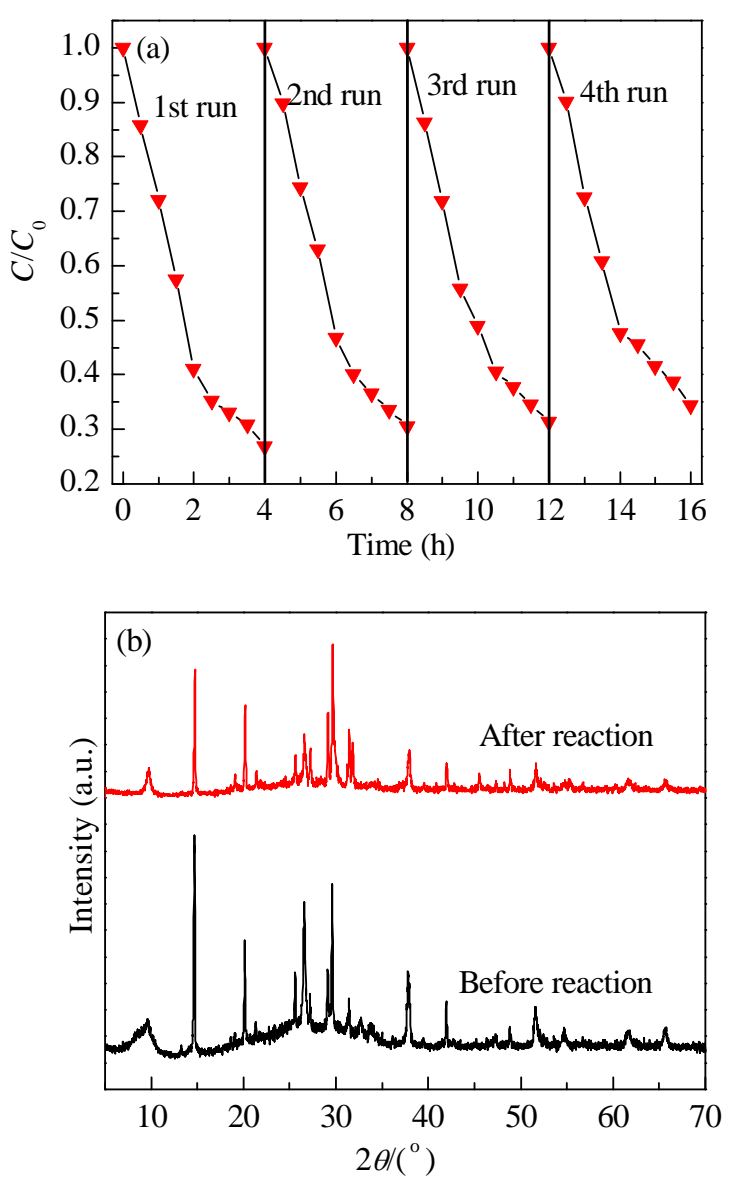

Fig. 15. (a) Tetracycline degradation cycling tests using the Bi$\mathrm{OI} / \mathrm{BiPO}_{4} / \mathrm{FTO}_{-150 s}$ electrode; (b) XRD patterns of $\mathrm{BiOI} / \mathrm{BiPO}_{4} / \mathrm{FTO}_{-150 \mathrm{~s}}$ electrode before and after four reaction cycles.

shown in Fig. 15(b), no changes in the phase or composition of the $\mathrm{BiOI} / \mathrm{BiPO}_{4} / \mathrm{FTO}_{-150 \text { s }}$ electrode occurred. This result indicates that $\mathrm{BiOI} / \mathrm{BiPO}_{4} / \mathrm{FTO}_{-150 \text { s }}$ remains stable throughout the photoelectrocatalytic reaction.

\section{Conclusions}

A BiOI/BiPO 4 composite film electrode was fixed to FTO glass by a simple and rapid two-step electrodeposition method. The 2D BiOI nanosheets were successfully deposited on the 1D $\mathrm{BiPO}_{4}$ nanorods to form a p-n heterojunction structure composite electrode. The composite electrode has excellent photoelectrocatalytic efficiency compared with pure BiOI/FTO electrodes and pure $\mathrm{BiPO}_{4} / \mathrm{FTO}$ electrodes because of its broader light absorption range and greater migration and separation efficiency of the electron-hole pairs. Trapping experiments suggest that hydroxyl $(\bullet \mathrm{OH})$ and superoxide radicals $\left(\bullet \mathrm{O}_{2}^{-}\right)$are the main reactive species in the PEC degradation process. The composite electrode material was extremely stable and is a promising material for PEC-based oxidative water purification.

\section{References}

[1] J. C. Ma, G. W. Stevens, K. A. Mumford, Chem. Eng. J., 2018, 347, 415-423.

[2] L. H. Li, Y. M. Kong, H. W. Kim, Y. W. Kim, H. E. Kim, S. J. Heo, J. Y. Koak, Biomaterials, 2004, 25, 2867-2875.

[3] N. P. Noyma, L. de Magalhaes, L. L. Furtado, M. Mucci, F. van Oosterhout, V. L. M. Huszar, M. M. Marinho, M. Lurling, Water Res., 2016, 97, 26-38.

[4] Y. G. Li, H. L. Wang, L. M. Xie, Y. Y. Liang, G. S. Hong, H. J. Dai, J. Am. Chem. Soc., 2011, 133, 7296-7299.

[5] X. Q. Liu, J. Iocozzia, Y. Wang, X. Cui, Y. H. Chen, S. Q. Zhao, Z. Li, Z. Q. Lin, Energy Environ. Sci., 2017, 10, 402-434.

[6] Q. Hao, S. Hao, X. Niu, X. Li, D. Chen, H. Ding, Chin. J. Catal., 2017, 38, 278-286.

[7] L. Qian, P. F. Liu, L. Zhang, C. W. Wang, S. Yang, L. R. Zheng, A. P. Chen, H. G. Yang, Chin. J. Catal., 2017, 38, 1045-1051.

[8] H. Q. Sun, G. L. Zhou, Y. X. Wang, A. Suvorova, S. B. Wang, ACS Appl. Mater. Interfaces, 2014, 6, 16745-16754.

[9] Q. J. Xiang, J. G. Yu, M. Jaroniec, Chem. Soc. Rev., 2012, 41, 782-796.

\section{Graphical Abstract}

Chin. J. Catal., 2019, 40: 446-457 doi: 10.1016/S1872-2067(18)63186-9

\section{Preparation of a p-n heterojunction 2D BiOI} nanosheet/1DBiPO 4 nanorod composite electrode for enhanced visible light photoelectrocatalysis

Sen Liu, Mengyu Zhao, Zetian He, Yi Zhong, Hao Ding, Daimei Chen * China University of Geosciences

The p-n heterojunction structure promotes the separation and migration of photogenerated charges leading to enhanced photoelectrocatalytic efficiency in the $\mathrm{BiOI} / \mathrm{BiPO}_{4} / \mathrm{FTO}$ electrode.

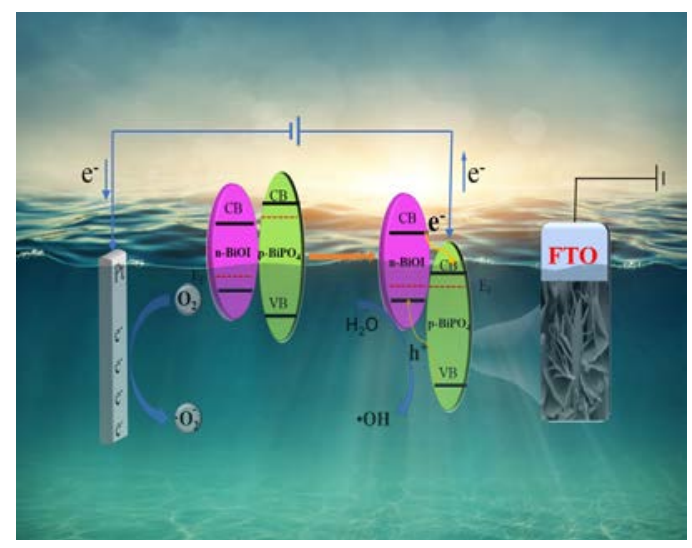


[10] D. M. Chen, Z. H. Wang, T. Z. Ren, H. Ding, W. Q. Yao, R. L. Zong, Y. F. Zhu, J. Phys. Chem. C, 2014, 118, 15300-15307.

[11] X. Q. Hao, J. Zhou, Z. W. Cui, Y. C. Wang, Y. Wang, Z. G. Zou, Appl. Catal. $B, 2018,229,41-51$.

[12] Q. Z. Wang, T. J. Niu, L. Wang, J. W. Huang, H. D. She, Chin. J. Catal., 2018, 39, 613-618.

[13] G. Yang, D. M. Chen, H. Ding, J. J. Feng, J. Z. Zhang, Y. F. Zhu, S. Hamid, D. W. Bahnemann, Appl. Catal. B, 2017, 219, 611-618.

[14] Y. N. Su, G. Q. Tan, T. Liu, L. Lv, Y. Wang, X. L. Zhang, Z. W. Yue, H. J. Ren, A. Xia, Appl. Surf. Sci., 2018, 457, 104-114.

[15] P. Y. Kuang, L. Y. Zhang, B. Cheng, J. G. Yu, Appl. Catal. B, 2017, 218, 570-580.

[16] W. Teng, Y. M. Wang, H. H. Huang, X. Y. Li, Y. B. Tang, Appl. Surf. Sci., 2017, 425, 507-517.

[17] Q. F. Cheng, J. Xu, T. Wang, L. Fan, R. F. Ma, X. Z. Yu, J. Zhu, Z. Xu, B. A. Lu, Appl. Surf. Sci., 2017, 422, 528-535.

[18] C. M. Ding, J. Y. Shi, Z. L. Wang, C. Li, ACS Catal., 2017, 7, 675-688.

[19] C. S. Pan, Y. F. Zhu, Environ. Sci. Technol., 2010, 44, 5570-5574.

[20] C. S. Pan, D. Li, X. G. Ma, Y. Chen, Y. F. Zhu, Catal. Sci. Technol., 2011, 1, 1399-1405.

[21] K. Ding, D. Yu, W. Wang, P. Gao, B. J. Liu, Appl. Surf. Sci., 2018, 445, 39-49.

[22] Z. G. Qiu, T. Zeng, K. H. Ye, X. Yu, Y. Zhu, Y. M. Zhang, J. Electrochem. Soc., 2016, 163, H18-H23.

[23] C. Y. Zhai, J. Y. Hu, M. J. Sun, M. S. Zhu, Appl. Surf. Sci., 2018, 430, 578-584.

[24] R. A. He, S. W. Cao, P. Zhou, J. G. Yu, Chin. J. Catal., 2014, 35, 989-1007.

[25] S. Y. Wu, H. Zheng, Y. W. Lian, Y. Y. Wu, Mater. Res. Bull., 2013, 48, 2901-2907.

[26] H. Xu, Y. G. Xu, H. M. Li, J. X. Xia, J. Xiong, S. Yin, C. J. Huang, H. L. Wan, Dalton Trans., 2012, 41, 3387-3394.

[27] Z. H. Wu, J. Liu, Q. Y. Tian, W. Wu, ACS Sustain. Chem. Eng., 2017, 5, 5008-5017.

[28] C. S. Pan, J. Xu, Y. J. Wang, D. Li, Y. F. Zhu, Adv. Funct. Mater., 2012, 22, 1518-1524.

[29] Q. Z. Han, R. Y. Wang, B. Xing, T. Zhang, M. S. Khan, D. Wu, Q. Wei,
Biosens. Bioelectron., 2018, 99, 493-499.

[30] J. Di, J. X. Xia, S. Yin, H. Xu, L. Xu, Y. G. Xu, M. Q. He, H. M. Li, J. Mater. Chem. A, 2014, 2, 5340-5351.

[31] D. M. Chen, J. J. Yang, Y. Zhu, Y. M. Zhang, Y. F. Zhu, Appl. Catal. B, 2018, 233, 202-212.

[32] H. P. Ma, J. Zhang, Z. F. Liu, Appl. Surf. Sci., 2017, 423, 63-70.

[33] H. Wang, Y. H. Liang, L. Liu, J. S. Hu, P. Wu, W. Q. Cui, Appl. Catal. B, 2017, 208, 22-34.

[34] X. Zhang, L. Z. Zhang, T. F. Xie, D. J. Wang, J. Phys. Chem. C, 2009, 113, 7371-7378.

[35] Q. B. Li, H. Qin, H. K. Zhao, X. Zhao, X. F. Cheng, W. L. Fan, Appl. Surf. Sci., 2018, 457, 59-68.

[36] L. M. Sun, L. Xiang, X. Zhao, C. J. Jia, J. Yang, Z. Jin, X. F. Cheng, W. L. Fan, ACS Catal., 2015, 5, 3540-3551.

[37] F. Dong, Y. J. Sun, M. Fu, Z. B. Wu, S. C. Lee, J. Hazard. Mater., 2012, 219, 26-34.

[38] J. J. Jiang, P. Zhao, L. Q. Shi, X. Z. Yue, Q. Q. Qiu, T. F. Xie, D. J. Wang, Y. H. Lin, Z. Mu, J. Colloid Interface Sci., 2018, 518, 102-110.

[39] D. M. Chen, K. W. Wang, D. G. Xiang, R. L. Zong, W. Q. Yao, Y. F. Zhu, Appl. Catal. B, 2014, 147, 554-561.

[40] P. Y. Kuang, Y. Z. Su, G. F. Chen, Z. Luo, S. Y. Xing, N. Li, Z. Q. Liu, Appl. Surf. Sci., 2015, 358, 296-303.

[41] P. Y. Kuang, Y. Z. Su, K. Xiao, Z. Q. Liu, N. Li, H. J. Wang, J. Zhang, ACS Appl. Mater. Interfaces, 2015, 7, 16387-16394.

[42] X. J. Wen, C. G. Niu, L. Zhang, G. M. Zeng, ACS Sustain. Chem. Eng., 2017, 5, 5134-5147.

[43] J. Cao, B. Y. Xu, H. L. Lin, S. F. Chen, Chem. Eng. J., 2013, 228, 482-488.

[44] Q. Hao, X. Niu, C. Nie, S. Hao, W. Zou, J. Ge, D. Chen, W. Yao, Phys. Chem. Chem.Phys., 2016, 18, 31410-31418.

[45] Y. F. Liu, W. Q. Yao, D. Liu, R. L. Zong, M. Zhang, X. G. Ma, Y. F. Zhu, Appl. Catal. B, 2015, 163, 547-553.

[46] P. Y. Kuang, J. R. Ran, Z. Q. Liu, H. J. Wang, N. Li, Y. Z. Su, Y. G. Jin, S. Z. Qiao, Chem. Eur. J., 2015, 21, 15360-15368.

[47] W. I. Park, G. C. Yi, Adv. Mater., 2004, 16, 87-90.

[48] C. Chen, W. M. Cai, M. C. Long, B. X. Zhou, Y. H. Wu, D. Y. Wu, Y. J. Feng, ACS Nano, 2010, 4, 6425-6432.

\title{
增强可见光光电催化活性的二维BiOI纳米片/一维BiPO 4 纳米棒p-n异质结 复合电极的制备
}

\author{
刘 森, 赵梦雨, 和泽田, 钟 义, 丁 浩, 陈代梅* \\ 中国地质大学(北京)材料科学与工程学院, 北京 100083
}

摘要: 光电催化是一种新型催化技术, 在去除水中有机物方面具有独特的优势. 在光电协同作用下具有较高的量子效率, 电子-空缺负荷率低, 稳定性好等优势. $\mathrm{BiPO}_{4}$ 具有较宽的禁带宽度, 只能响应有限的紫外光区域, 极大限制了其光电催化效 率. 因此, 本文在电化学三电极体系下, 通过简单的两步电沉积法将 $\mathrm{BiPO}_{4}$ 纳米棒/ $\mathrm{BiOI}$ 纳米片复合薄膜沉积固定在FTO玻 璃上, 制备了 $\mathrm{BiPO}_{4} / \mathrm{BiOI} / \mathrm{FTO}$ 复合光电极材料. 通过场发射扫描电镜, 透射电子电镜, X射线光单子能谱、紫外可见漫反射 光谱以及电化学测试对其组成、晶体形貌结构和光学性质进行表征. 考察了外加工作电压、碘氧铋电极沉积时间等因素 对四环素去除效果的影响. 结果表明, $\mathrm{BiOI}$ 纳米片生长在 $\mathrm{BiPO}_{4}$ 纳米棒上, 形成了异质结结构, $\mathrm{BiPO}_{4} / \mathrm{BiOI} / \mathrm{FTO}$ 复合薄膜电 极具有良好的光吸收性能和优异的电荷转移特性. 当碘氧铋沉积时间为 $150 \mathrm{~s}$, 外加偏压为 $1.2 \mathrm{~V}$ 时, 复合薄膜电极具有最佳 的四环素去除效率, $4 \mathrm{~h}$ 达到 $80 \%$. 在相同的实验条件下, $\mathrm{BiPO}_{4} / \mathrm{BiOI} / \mathrm{FTO}$ 复合薄膜电极对四环素的去除效率分别是 $\mathrm{BiPO}_{4} / \mathrm{FTO}$ 电极和BiOI/FTO电极的1.6倍和1.4倍. 在光电协同作用下, $\mathrm{BiPO}_{4} / \mathrm{BiOI} / \mathrm{FTO}$ 复合光电极对污染物的去除效率是 单纯光催化和电催化对污染物去除效率的 2.8 倍和 2.5 倍. 同时该复合光电极具有好的稳定性, 经过四次 $16 \mathrm{~h}$ 的循环实验, 光 电极对四环素的去除效果基本保持不变.

根据一系列表征结果和p-n异质结形成的方式, 推测了 p-n 异质结的结构和反应过程. 在光激发作用下, BiOI导带上的 
光生电子有效的转移到 $\mathrm{BiPO}_{4}$ 导带上, 然后在外加偏压的作用下通过外电路转移到铂丝电极上, 光生电子与氧气反应生产 超氧自由基降解有机污染物. 另一方面, 光生空穴从 $\mathrm{BiPO}_{4}$ 价带上转移到 $\mathrm{BiOI}$ 价带上, 与水反应生产着基自由基, 作为光电 催化反应过程中的主要活性物种. 总之, 增强的光电催化活性BiOI/ $\mathrm{BiPO}_{4}$ 异质结构可能主要归因于p-n异质结结构改善催 化剂的光吸收能力和有效的电子-空穴转移过程.

关键词: 电沉积; 光电催化; $\mathrm{BiOI} / \mathrm{BiPO}_{4} / \mathrm{FTO}$; 四环素

收稿日期: 2018-08-31. 接受日期: 2018-10-13. 出版日期: 2019-03-05.

*通讯联系人. 电话: 15801558907; 电子信箱: chendaimei@cugb.edu.cn

基金来源：国家自然科学基金(21577132); 中央大学基础研究基金(2652017377, 2652017378).

本文的电子版全文由Elsevier出版社在ScienceDirect上出版(http://www.sciencedirect.com/science/journal/18722067). 